\title{
Evaluation of the Level and Impact of Selected Physiochemical Parameters of Fertilizer Effluent on Obinna River, Adani, Enugu State, Nigeria
}

\author{
Chizoba Chinelo Agu1 ${ }^{*}$, Matthew Chukwudi Menkiti², Bernard Ibezim Okolo ${ }^{3}$, \\ Patrick Chukwudi Nnaji ${ }^{3}$ \\ ${ }^{1}$ Center for Environmental Management and Control (CEMAC), University of Nigeria, Enugu, Nigeria \\ ${ }^{2}$ Department of Chemical Engineering, Nnamdi Azikiwe University, Awka, Nigeria \\ ${ }^{3}$ Department of Chemical Engineering, Michael Okpara University of Agriculture, Umudike, Nigeria \\ Email: ${ }^{*}$ aguzoba@yahoo.com
}

Received 1 March 2014; revised 2 April 2014; accepted 29 April 2014

Copyright (C) 2014 by authors and Scientific Research Publishing Inc.

This work is licensed under the Creative Commons Attribution International License (CC BY).

http://creativecommons.org/licenses/by/4.0/

(c) (i) Open Access

\begin{abstract}
This work quantitatively evaluates the level and impact of selected physiochemical properties of fertilizer effluent on the Obinna River of Adani, Enugu State, Nigeria. The fertilizer effluent originated from surrounding farms and flushed into the Obinna River. Water samples were collected from designated points along the river and analysed for physical, chemical and biological properties using standard methods of APHA. Impact of selected key parameters such as nitrate, phosphate, manganese, dissolved oxygen, biochemical oxygen demand and heavy metals (lead, iron and manganese), was studied. The results of the parameters were compared with the World Health Organisation (WHO) permissible standard for freshwater. Measured concentrations of phosphate $(5.00,7.21,3.92 \mathrm{mg} / \mathrm{L})$, manganese $(1.53,1.18,1.47 \mathrm{mg} / \mathrm{L})$ and lead $(18.9,21.7,39.7$ ppm) were found to be above the WHO standard while nitrate $(0.04,0.03,0.03 \mathrm{mg} / \mathrm{L})$ and iron $(0.001,0.001,0.1 \mathrm{mg} / \mathrm{L})$ were within the standard. The mean concentrations of heavy metals increased in the following order: Fe $(0.034)<\mathrm{Mn}(1.4)<\mathrm{Pb}(26.8)$ from upstream $\mathrm{S}_{1}$ to downstream $S_{3}$, with manganese and lead being above WHO standard. The results showed a level of significance for the chi-square distribution and correlation coefficients while the analysis of variance (ANOVA) results was conflicting. It could be inferred that the impact of the selected parameters contributed to the pollution of Obinna River.
\end{abstract}

\section{Keywords}

Physiochemical, Heavy Metals, WHO, Pollution, Obinna River

\footnotetext{
*Corresponding author.
}

How to cite this paper: Agu, C.C., et al. (2014) Evaluation of the Level and Impact of Selected Physiochemical Parameters of Fertilizer Effluent on Obinna River, Adani, Enugu State, Nigeria. Journal of Water Resource and Protection, 6, $722-730$.

http://dx.doi.org/10.4236/jwarp.2014.67069 


\section{Introduction}

A major cause of freshwater scarcity is the application of agricultural chemicals such as chemical fertilizers and pesticides for assured "better" resource harvesting. These chemical fertilizers contain volumes of elements ranging from macro nutrients such as nitrates, phosphates and potassium to secondary plant nutrients and trace elements such as calcium, magnesium, sulphur, boron, manganese, iron, molybdenum and copper. The use of these agricultural chemicals induces pressure on ecosystems and can directly or indirectly, positively or negatively affect the services of a functioning ecosystem. And, as long as the world faces an increase in global, regional and local populations, there will always be some added pressure on the natural resource base- - the land, for increased food production. [1] noted that the most common causes of water body impairment are sediments, pathogens, nutrients, metals, dissolved oxygen and other habitat alteration and agricultural practices, which provide the focus of this study.

Agriculture is the major source of nitrate and phosphate pollution of surface water [2]. Agriculture further contributes to a doubling of nitrogen fixation [3] [4] and a tripling of phosphorous usage [4] [5]. Nitrate may arise from the excessive application of fertilizers or from leaching of wastewater or other organic wastes into surface water and ground water [6]. Taiwo et al. [2] noted that nutrient enrichment is predominant in most rivers in Nigeria. Increasing the nutrient (phosphorous and nitrate) concentrations in freshwater, can lead to eutrophication in lakes and rivers as a result of a decrease in the amount of oxygen available to aquatic life, killing fish and other aquatic organisms [7].

Furthermore, heavy metals are potential toxic threats to the environment and ecosystem due to their persistence and bio-accumulation in the food chain, water and organisms [2] [8] [9]. Their accumulation above recommended level is undesirable [10] [11]. Such toxic heavy metals include $\mathrm{Hg}, \mathrm{Pb}, \mathrm{As}, \mathrm{Cd}, \mathrm{Fe}, \mathrm{Co}, \mathrm{Mn}, \mathrm{Cr}$, etc. [11] [12], though heavy metals like iron, copper, zinc, nickel, and other trace elements are needed for proper functioning of biological systems. Deficiencies of these trace elements may lead to a number of disorders [13] [14].

Freshwater supplies and wastewaters are known to have a high degree of variability in terms of physico-chemical quality, heavy metal concentration and microbial quality [14]. And as part of global efforts to promote sustainable development, two of the commitments of the World Summit on Sustainable Development (WSSD) in 2002 at Johannesburg include 1) by 2020, that chemicals should be used and produced in ways that do not harm human health and the environment 2) halving the proportion of people without access to safe drinking water by 2015.

It was reported that at least 27 per cent of Nigerians depended absolutely on streams, ponds, rivers and rainwater for their drinking water sources [2] [15]. And also, by 2025, Nigeria would be among 48 countries expected to experience water shortage below the United Nations Development Programme (UNDP) threshold to the tone 1000 to $1700 \mathrm{M}^{3}$ /person/year [16].

In view of the prevailing challenges, this study becomes very imperative. Thus it attempts to assess the effects of leaching of fertilizer effluent into the Obinna River. Key parameters were identified, quantified and compared with World Health Organisation (WHO) standard, in order to evaluate the level of compliance with the standard. Also, statistical analyses of the result were conducted to evaluate the statistical significance of the obtained results.

\section{Materials and Methods}

\subsection{Study Area}

The study was carried out on the Obinna River and samples were collected during high stream flow conditions at a temperature of $26^{\circ} \mathrm{C}$.

The Obinna River is surrounded by lush vegetation of thick trees and shrubs along its banks. It is located at Adani, Uzo-Uwani local government area in Enugu state, Nigeria. And being part of the Anambra river system, it lies on $7^{\circ} 11^{\prime}{ }^{\prime \prime}$ East of the Greenwich meridian and $6^{\circ} 45^{\prime} 0^{\prime \prime}$ North of the equator.

Located on the left bank of the river is Adarice farmlands of about 900 hectares. Over the years, the river received fertilizer effluent from this farm and by 2006; the river supplied water for domestic and farm needs as well as natural habitat to aquatic flora and fauna. The map (Figure 1) on the following page shows Adani where the Obinna River is located

\subsection{Sample Characterization and Analysis}

\subsubsection{Field Study}

The study was limited to three sample points $S_{1}, S_{2}$ and $S_{3}$ representing 1) upstream: the river before the point of 


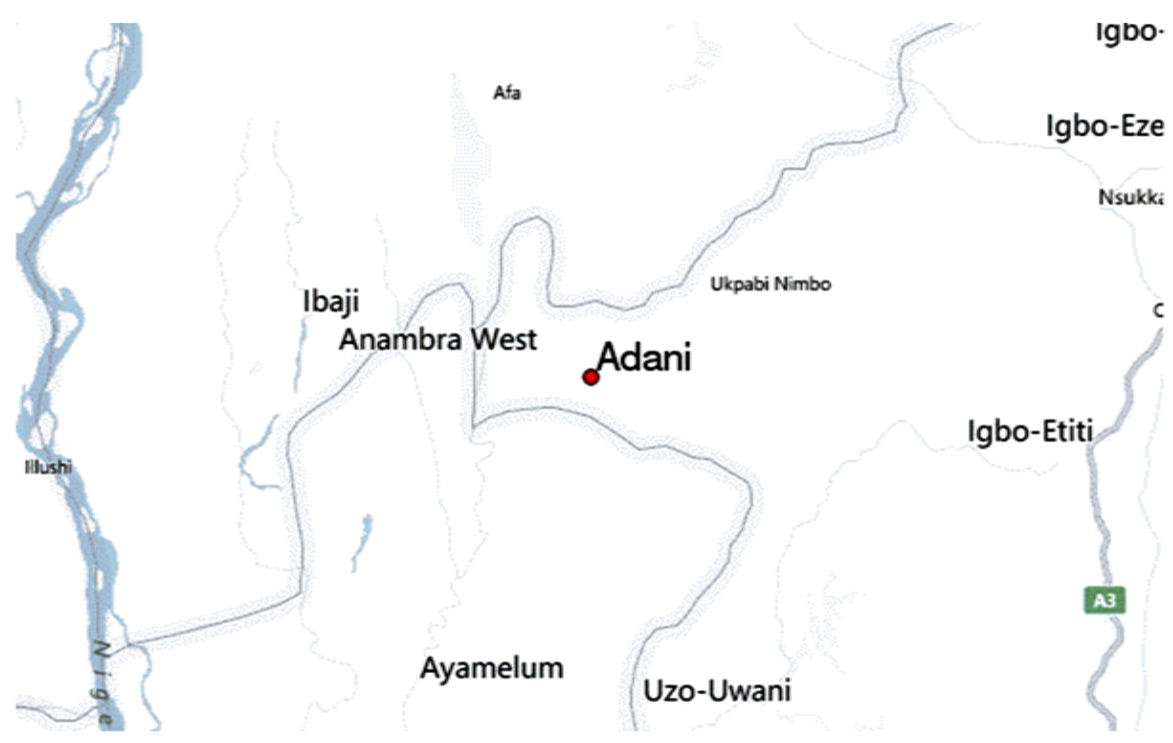

Figure 1. Location of sampling site. Source: [17].

wastewater discharge, 2) midstream: the river at the point of wastewater discharge and 3) downstream: the river after the point of wastewater discharge.

Precautions were taken to ensure that the samples were representative of the river.

\subsubsection{Laboratory Analysis}

The characteristics of the water samples (Table 1) were determined by standard APHA method [18]. The quantity of heavy metals was determined by Atomic Absorption Spectrophotometry.

\subsubsection{Statistical Analysis}

1) Determination of the per cent change from $S_{1}$ to $S_{2}$

$$
\left[\frac{S_{1}-S_{2}}{S_{1}}\right] \times 100
$$

$S_{1}$ is the expected concentration;

$S_{2}$ is the observed concentration.

2) Determination of the chi-square $\boldsymbol{X}^{2}$ for the measured samples

$$
X^{2}=\sum_{i=1}^{n} \frac{\left(O_{i}-E_{i}\right)^{2}}{E_{i}}
$$

$O_{i}$ is the observed concentration;

$E_{i}$ is the expected concentration (WHO standard);

$\boldsymbol{n}$ is the number of cases.

3) Determination of the extent of a correlation using the Pearson's linear coefficient IrI

$$
I r I=\frac{\sum(X-\bar{X})(Y-\bar{Y})}{\sum \sqrt{(X-\bar{X})^{2}(Y-\bar{Y})^{2}}}
$$

$X$ and $Y$ are the pairs of observation;

$\bar{X}$ and $\bar{Y}$ are the mean of pairs of observation.

4) Determination of the mean concentration $(\boldsymbol{S})$ of heavy metals in water samples.

$$
S=\frac{S_{1}+S_{2}+S_{n}}{n}
$$




$$
=\frac{1}{n} \sum_{i=1}^{n} X_{i}
$$

$S_{1}, S_{2}$ and $S_{n}$ are the variates of heavy metals observed;

$\boldsymbol{n}$ is the total number of observations.

5) Determination of difference using ANOVA and the Coefficient of Variation (CV \%)

$$
\text { Coefficient of variation }=\frac{\sqrt{\text { variance }}}{\text { Grand mean }} \times 100
$$

\section{Results and Discussion}

\subsection{Nitrate, Phosphate, BOD and DO Concentrations}

Sigmund [19] suggests a maximum level of $0.1 \mathrm{mg} / \mathrm{L}$ as the expected level of phosphate in surface stream water. FEPA [20] and Adelekan et al. [21] prescribed maximum concentrations of DO and BOD of $2.0 \mathrm{mg} / \mathrm{L}$ and 30 $\mathrm{mg} / \mathrm{L}$ respectively for surface water. These levels suggested that the river was highly polluted at the time of the study.

The phosphate concentration showed a higher per cent change with an increase of 44.2 per cent from $S_{1}$ to $S_{2}$ while nitrate showed a 25 per cent drop in concentration. The recorded increase in phosphate concentration at $S_{2}$ may suggest 1) production of phosphate as a result of the decomposition of organic matter. According to Taiwo [2] and Ogunfowokan [22], "organic matter decomposition in surface water produces inorganic nutrients such as ammonia, nitrate and phosphate with resulting effects of eutrophication and other serious ecological problems of such water body"; 2) the use of phosphate based fertilizer during the 2006 rice planting season might have resulted in the increased in phosphate load at $\mathrm{S}_{2} ; 3$ ) nitrate may be the limiting factor in the river.

(Table 1) No specific trend was observed in the nitrate, phosphate, BOD and DO levels from $\mathrm{S}_{1}$ to $\mathrm{S}_{3}$. However, there were significant levels of concentration in the nitrate, phosphate and BOD levels. These are shown in the results for the Chi-square distribution (Table 2). The concentrations of analysed parameters are shown to be significant at the 5 per cent (5.99) confidence limit.

(Table 3) A correlation between the statistically analysed parameters ( 5 per cent confidence limit) was shown with the strongest correlation observed between the BOD and DO $\left(\operatorname{IrI}=0.9, \mathrm{r}^{2}>0.999\right)$ and the weakest between BOD and nitrate ( IrI $\left.=0.3, \mathrm{r}^{2}>0.999\right)$. A negative correlation was established between nitrate and phosphate concentrations. An increase in BOD and an expected drop in DO levels observed in the river at $\mathrm{S}_{2}$ could suggest higher levels of decaying organic matter during the time of the study. As a result of the water becoming anaerobic due to oxygen depletion in water bodies, fish could die and an increase in BOD concentration signifies organic load [2]. Also, Adelekan [21] noted that BOD is a common measure of water quality and it reflects the degree of organic matter pollution of a water body.

The F-test (Table 4) shows that 0.92 is less than the critical value of 5.14 (5 per cent confidence limit) with the coefficient of variation calculated as 8.2 per cent. Less than 10 per cent contribution.

\subsection{Heavy Metals Concentration}

There was a 22.9 per cent drop in manganese concentration and a 14.8 per cent increase in lead concentration from $S_{1}$ to $S_{2}$. A 14.8 per cent increase in lead concentration at $S_{2}$, could suggest the presence of lead in the wastewater discharged from the rice farms. Perhaps from the use of an underground lead pipe network (for wastewater drainage) connected to a disused gravity irrigation system situated within Adarice farmlands. Agarwal [23] and Silambarasan [24] noted that problems exist in areas with soft slightly alkaline water which may dissolve lead from lead pipes. Adelekan [21] suggests that as the $\mathrm{pH}$ levels drop below 7.0; corrosion of water pipes may occur, resulting in the release of metals into drinking water.

A very high significant value of $\mathrm{x}^{2}$ was established for $\mathrm{Pb}$ concentrations and non-significant values for $\mathrm{Fe}$ and Mn (Table 2). Also, values of $\operatorname{IrI}<1$ and $>0$ (Table 3), indicate evidence of a correlation existing between the heavy metals with the strongest correlation observed between $\mathrm{Pb}$ and $\mathrm{Fe}\left(\mathrm{IrI}=0.99 \mathrm{r}^{2}>0.999\right)$ and the weakest between $\mathrm{Pb}$ and $\mathrm{Mn}\left(\mathrm{IrI}=0.24, \mathrm{r}^{2}>0.999\right)$. This could suggest a common source. The mean concentra tion of heavy metals showed the highest concentration to be at $S_{3}$ (Figure 2) suggesting 1) there could be other sources of heavy metals in the river besides the suspected agricultural wastewater from point source at $\mathrm{S}_{2} .2$ ) 
Table 1. Surface water analysis result for the Obinna River.

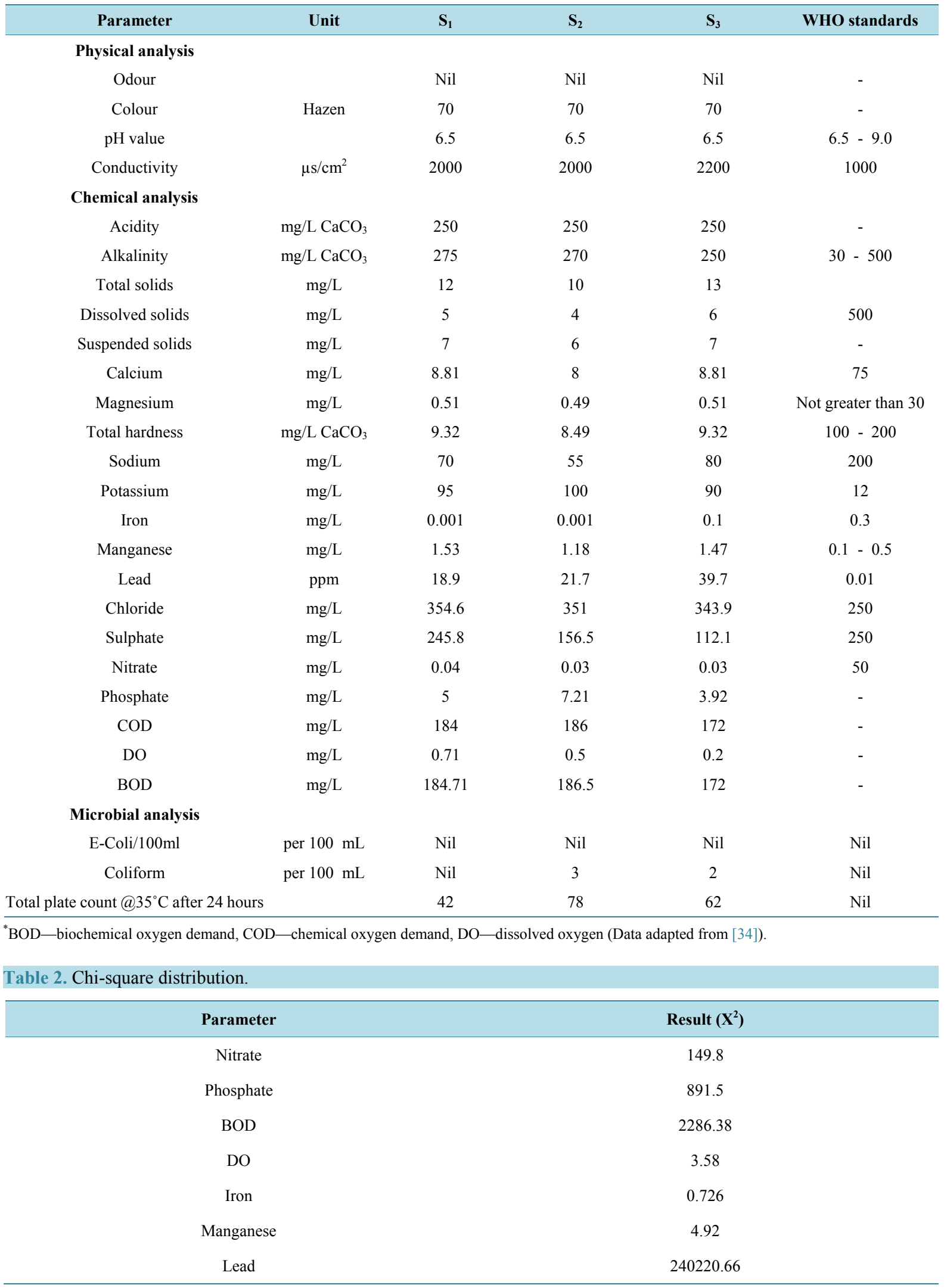


Table 3. Coefficients of linear Pearson's correlation IrI in surface water considering all samples from the Obinna River.

\begin{tabular}{|c|c|c|c|c|}
\hline \multicolumn{5}{|c|}{ Non Metals } \\
\hline & Nitrate & Phosphate & DO & BOD \\
\hline Nitrate & 1 & $-0.9^{\text {n.s }}$ & $0.7^{*}$ & $0.3^{*}$ \\
\hline Phosphate & & 1 & $0.4^{*}$ & $0.8^{*}$ \\
\hline DO & & & 1 & $0.9^{*}$ \\
\hline BOD & & & & 1 \\
\hline \multicolumn{5}{|c|}{ Heavy Metals } \\
\hline & Iron & Manganese & Lead & \\
\hline Iron & 1 & $0.35^{*}$ & $0.99^{*}$ & \\
\hline Manganese & & 1 & $0.24^{*}$ & \\
\hline Lead & & & 1 & \\
\hline
\end{tabular}

n. s, not significant $\left(\mathrm{r}^{2}>0.999\right),{ }^{*}$ Significant Correlation $\left(\mathrm{r}^{2}>0.999\right)$.

Table 4. Difference in the mean concentrations of water samples.

\begin{tabular}{|c|c|c|c|}
\hline $\begin{array}{l}\text { Source of variation for the } \\
\text { non-metals }\end{array}$ & Sum of squares & Degrees of freedom & $\begin{array}{l}\text { Variance estimate for } \\
\text { the non-metals }\end{array}$ \\
\hline Between water samples & 14787.56 & 2 & $14787.56 / 2$ \\
\hline Within water samples & 72318.92 & 9 & $72318.92 / 9$ \\
\hline Total & 87104.4 & 11 & \\
\hline $\begin{array}{c}\text { Source of variation for the } \\
\text { heavy metals }\end{array}$ & Sum of squares & Degrees of freedom & $\begin{array}{l}\text { Variance estimate for the } \\
\text { heavy metals }\end{array}$ \\
\hline Between water samples & 86.88 & 2 & $86.88 / 2$ \\
\hline Within water sample & 1528.7 & 6 & $1528.7 / 6$ \\
\hline Total & 1615.58 & 8 & \\
\hline
\end{tabular}

there may have been some increase in pollution load downstream at $S_{3}$ perhaps, due to the movement of suspended and dissolved materials.

(Figure 2 and Figure 3) The mean concentrations of heavy metals in the water samples indicate $\mathrm{S}_{1}=6.8$ $\mathrm{mg} / \mathrm{L}, \mathrm{S}_{2}=7.6 \mathrm{mg} / \mathrm{L}$ and $\mathrm{S}_{3}=13.8 \mathrm{mg} / \mathrm{L}$ and also, iron $(\mathrm{Fe})=0.34 \mathrm{mg} / \mathrm{L}$, manganese $(\mathrm{Mn})=1.40 \mathrm{mg} / \mathrm{L}$ and lead $(\mathrm{Pb})=26.8 \mathrm{mg} / \mathrm{L}$. At $\mathrm{S}_{3}, 39.7 \mathrm{ppm}$ or $\mathrm{mg} / \mathrm{L}$ of lead contributed to the mean concentration of heavy metals $(13.8 \mathrm{mg} / \mathrm{L})$ with lead concentrations increasing from $\mathrm{S}_{1}$ to $\mathrm{S}_{3}$ (Table 1). According to Merhotra et al. [25] and Chakravaty et al. [26] "where stagnant condition prevails at the bottom of a river, the dissolved oxygen is completely removed.

As a result, free metallic complexes are formed which influence the solubility of metal "lead" by forming insoluble complexes. These complexes tend to strip the water of its metal content and enrich the bottom sediments with the metal". Near anaerobic conditions were observed at all points in the river (Table 1) with a decrease in concentration from upstream at $\mathrm{S}_{1}$ to downstream at $\mathrm{S}_{3}$.

It can be observed (Figure 3 ) that there was a trend in the increase in heavy metal concentrations along the river from upstream at $\mathrm{S}_{1}$ to downstream at $\mathrm{S}_{3}$ as follows $\mathrm{Fe}<\mathrm{Mn}<\mathrm{Pb}$. The variance estimates (Table 5) show no significant change in the water quality as a result of the heavy metals present in the water samples. The coefficient of variation (Table 5) also shows less than 10 per cent (4.4 per cent) contributions from analysed parameters to the surface water.

Manganese is an essential metal that at excessive levels in the brain produces extra pyramidal symptoms similar to those in patients with Parkinson's disease [21] [27], and decreased learning ability in school age children and increased propensity for violence in adults [21] [28].

Lead is a particularly dangerous metal which has no biological role [21] [29]. Lead is a cumulative toxicant 


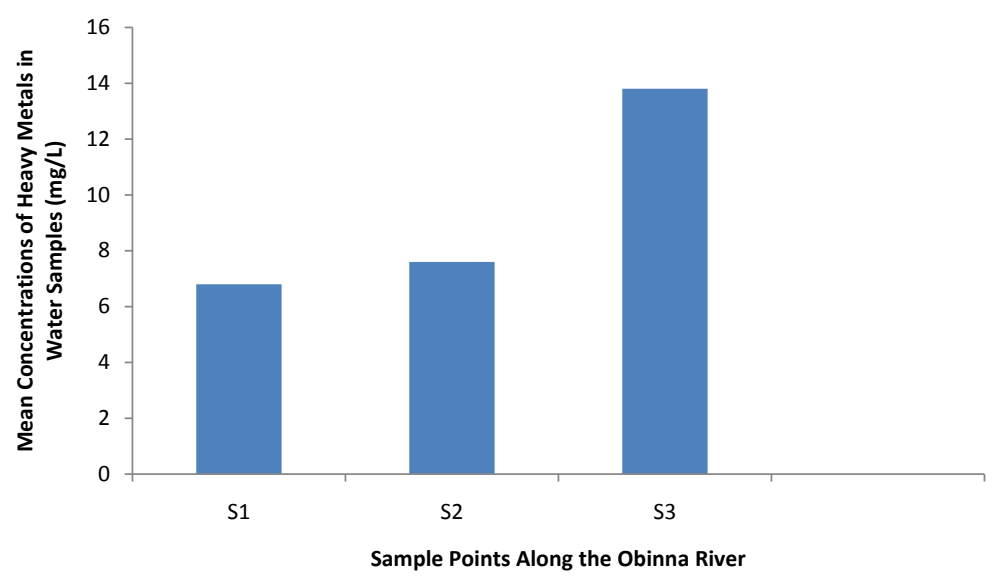

Figure 2. Variations in the mean concentrations of heavy metals in water samples.

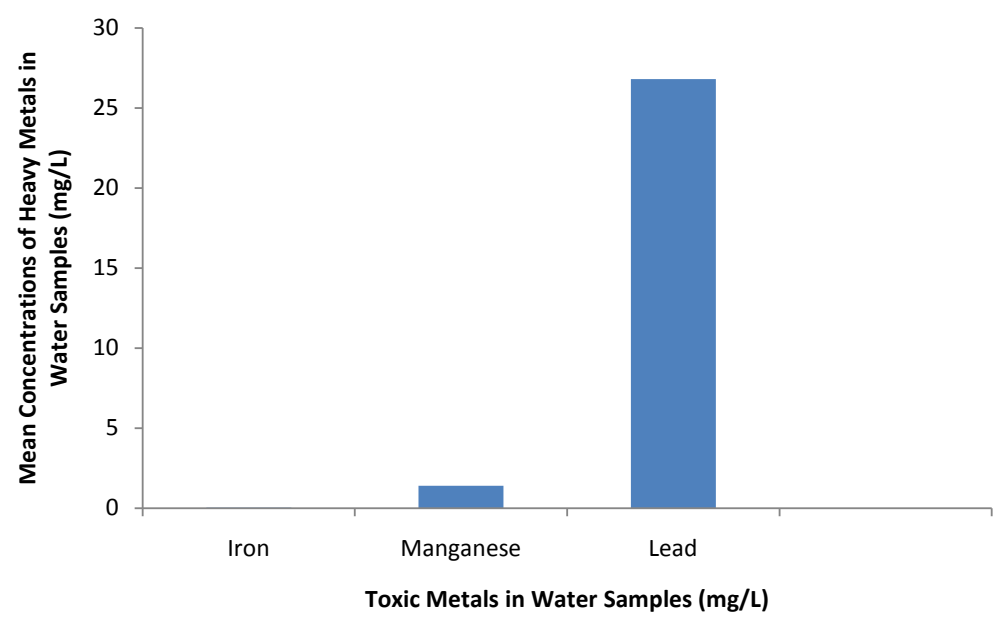

Figure 3. Variations in the mean concentrations of heavy metals in water samples.

Table 5. Standard deviation of analysed parameters.

\begin{tabular}{|c|c|c|c|c|c|c|c|}
\hline Parameter & $\mathbf{S}_{1}$ & $\mathbf{S}_{2}$ & $\mathbf{S}_{3}$ & Mean value & Grand mean & variance & $\begin{array}{l}\text { Standard } \\
\text { deviation }\end{array}$ \\
\hline$(\mathrm{mg} / \mathrm{L})$ & & & & & & & $\left({ }^{\circ}\right)$ \\
\hline Nitrate & 0.04 & 0.03 & 0.03 & 0.03 & & & \\
\hline Phosphate & 5 & 7.21 & 3.92 & 5.38 & & & \\
\hline DO & 0.71 & 0.5 & 0.2 & 0.47 & & & \\
\hline BOD & 184.71 & 186.5 & 172 & 181.07 & & & \\
\hline Mean value & 47.62 & 48.56 & 44.04 & & 11.69 & 0.92 & 0.96 \\
\hline Iron & 0.001 & 0.001 & 0.1 & 0.034 & & & \\
\hline Manganese & 1.53 & 1.18 & 1.47 & 1.4 & & & \\
\hline Lead & 18.9 & 21.7 & 39.7 & 26.8 & & & \\
\hline Mean value & 6.8 & 7.6 & 13.8 & & 9.4 & 0.17 & 0.41 \\
\hline
\end{tabular}


that affects multiple body systems, including the neurological, haematological, gastrointestinal, cardiovascular and renal systems. Chronic exposure commonly causes haematological effects, such as anaemia, or neurological disturbances, including headache, irritability, lethargy, convulsions, muscle weakness, ataxia, tremors and paralysis. Acute exposure may cause gastrointestinal disturbances (anorexia, nausea, vomiting, abdominal pain), lepatic and renal damage, hypertension and neurological effects (malaise, drowsiness, encephalopathy) that may lead to convulsions and death [30] [31].

Iron has an essential role as a constituent of enzymes, such as cytochromes and catalase, and of oxygen transporting proteins, such as haemoglobin and myoglobin. In fresh waters, iron is also an important nutrient for algae and other organisms. Due to its high abundance within the earth crust, Iron is ubiquitous in all fresh water environments and often reaches significantly higher concentrations in water and sediments than other trace metals. High iron concentration in fresh waters has long been considered a problem. In domestic use, iron-enriched waters may induce rust formation on plumbing fixtures, the staining of laundry and a metallic taste in drinking water. The mining of iron rich ores has caused the degradation of many river ecosystems [24] [32]. Excess of iron will also influence the presence of bacteria (Iron reducing) in fresh water. It affects target organs like liver, cardio vascular system and kidney [24] [33].

\section{Conclusion}

The results showed a level of significance for the chi-square distributions and correlation coefficients while the ANOVA recorded conflicting results. Statistically, there was no significant change in the surface water quality of the river as a result of iron and manganese concentrations. However, the presence of values of some parameters above WHO standard, indicates pollution of the river. It can be inferred that Obinna River recorded significant change in water quality of the river as a result of fertilizer leachates flushing into the river.

\section{References}

[1] Dale, V.H. and Polasky, S. (2007) Measure of the Effects of Agricultural Practices on Ecosystem Services. The Trans Disciplinary Journal of the International Society for Ecological Economics, 64, 286-298. www.elsevier.com/locate/ecolecon

[2] Taiwo, A.M., Olujimi, O.O., Bamgbose, O. and Arowolo, T.A. (2012) Surface Water Quality Monitoring in Nigeria: Situational Analysis and Future Management Strategy, Water Quality Monitoring and Assessment. InTech, Rijeka. http://www.intechopen.com/books/waterquality-monitoring-and-assessment/surface-water-quality-monitoring-in-nigeri a-situational-analysis-and-futuremanagement-strategy

[3] Galloway, J.N., et al. (2004) Nitrogen Cycles: Past, Present and Future. Biogeochemistry, 70, 153-226 http://dx.doi.org/10.1007/s10533-004-0370-0

[4] Horwitz, P., Max Finlayson, C. and Weinstein, P. (2012) Healthy Wetlands, Healthy People. A Review of Wetlands and Human Health Interactions. World Health Organisation, Ramsar Technical Report No. 6.

[5] Bennett, E.M., Carpenter, S.R. and Caraco, N.F. (2001) Human Impact on Erodible Phosphorous and Eutrophication: A Global Perspective. BioScience, 51, 227-234. http://dx.doi.org/10.1641/0006-3568(2001)051[0227:HIOEPA]2.0.CO;2

[6] World Health Organisation (2006) Guidelines for Drinking Water Quality. First Addendum to Third Edition, 1, WHO Genva.

[7] Revenga, C., Brunner, J., Henninger, N., Kassem, K. and Payne, R. (2000) Pilot Analysis of Global Ecosystems: Freshwater Ecosystems. World Resources Institute (WRI), Washington DC.

[8] Linnik, P.M. and Zubenko, I.B. (2000) Role of Bottom Sediments in the Secondary Pollution of Aquatic Environments by Heavy Metal Compounds: Lakes and Reservoirs. Research and Management, 5, 11-21. http://dx.doi.org/10.1046/j.1440-1770.2000.00094.x

[9] Ogoyi, D.O., Mwita, C.J., Nguu, E.K. and Shiundu, P.M. (2011) Determination of Heavy Metal Content in Water, Sediment and Micro Algae from Lake Victoria, East Africa. Open Environmental Engineering Journal, 4, $156-161$.

[10] Radojavic, M. and Vladimir, N.B. (1992) Bulletin of the Royal Society of Chemistry. London, 14.

[11] Elinge, C.M., Itodo, A.U., Peni, I.J., Birnim-Yauri, U.A. and Mbongo, A.N. (2011) Assessment of Heavy Metals Concentrations in Bore-Hole Waters in Aliero Community of Kebbi State. Advances in Applied Science Research, 2, 279-282. http://www.pelagiaresearchlibrary.com/

[12] Bhatia, C.S. (2001) Environmental Pollution and Control in Chemical Process Industries. 1st Edition, Khanna Publish- 
ers, Naisarak, Delhi, 23-25.

[13] Prabu, P.C. (2009) Impact of Heavy Metal Contamination of Akaki River of Ethiopia on Soil and Metal Toxicity on Cultivated Vegetable Crops. Electronic Journal of Environmental, Agricultural and Food Chemistry, 8, 818-827.

[14] Mufandaedza, J. and Kamusoko, R. (2012) Heavy Metal Analysis of Freshwater Supplies and Wastewaters: A Case of Chinhoyl and Harare. International Researchers, 1. www.iresearcher.org

[15] National Bureau of Statistics (2009) Social Statistics in Nigeria. 399 p. http://www.nigerianstat.gov.ng/ext/latest_release/ssd09.pdf

[16] Digout, D. and UNEP/GRID Arendal (2005) Water Availability in Africa. http://www.grida.no/publications/vg/Africa

[17] http://www.weather-forecast.com

[18] Clesceri, L.S., Greenberg, A.E. and Eaton, A.D. (1999) Standard Methods for the Examination of Water 602 and Wastewater. 20th Edition, APHA, Washington DC.

[19] Sigmund, C.A. (1996) Pristine Waters: Examining the Chemistry of Streams, Lakes, and Rivers. Langara Press, Vancouver, pp. 147.

[20] Federal Environmental Protection Agency (2006) Guidelines for Contaminant Content of Natural Waters. Federal Ministry of Environment, Abuja.

[21] Adelekan, B.A. and Ogunde, O.A. (2012) Quality of Water from Dug Wells and the Lagoon in Lagos Nigeria and Associated Health Risks. Scientific Research and Essays, 7, 1195-1211. http://www.academicjournals.org/SRE

[22] Ogunfowokan, A.O., Okoh, E.K., Adenuga, A.A. and Asubiojo, O.I. (2005) An Assessment of the Impact of Point Source Pollution from a University Sewage Treatment Oxidation Pond on a Receiving Stream-A Preliminary Study. Journal of Applied Sciences, 5, 36-43. http://dx.doi.org/10.3923/jas.2005.36.43

[23] Agarwal, S.K. (2005) Water Pollution. APH Publication, New Delhi, vii, 384 p.

[24] Silambarasan, K., Senthilkumaar, P. and Velmurugan, K. (2012) Studies on the Distribution of Heavy Metal Concentrations in River Adyar, Chennai Tamil Nadu. European Journal of Experimental Biology, 2, 2192-2198. Pelagia Research Library. http://www.pelagiaresearchlibrary.com

[25] Merhotra, M.N., Singh, S.N., Srivastava, A. and Singh, K.M. (1991) Lead in Bank Sediments of Ganga and Its Role in Water Pollution. Bulletin of Indian Geologists' Association, 24, 61-66.

[26] Chakravarty, M. and Patgiri, A.D. (2009) Metal Pollution Assessment in Sediments of the Dikrong River, N.E. India. Journal of Human Ecology, 27, 63-67.

[27] Vahter, M., Berglund, M., Åkesson, A. and Lidén, C. (2002) Metals and Women's Health. Environmental Research, 88, 145-155. http://dx.doi.org/10.1006/enrs.2002.4338

[28] Finley, J.W. (2004) Does Environmental Exposure to Manganese Pose a Health Risk to Healthy Adults? Nutrition Reviews, 62, 148-153.

[29] Sobolev, D. and Begonia, M.F.T. (2008) Effects of Heavy Metal Contamination upon Soil Microbes: Lead-Induced Changes in General and Denitrifying Microbial Communities as Evidenced by Molecular Markers. International Journal of Environmental Research and Public Health, 5, 450-456. http://dx.doi.org/10.3390/ijerph5050450

[30] World Health Organization (2010) Exposure to Lead: A Major Public Health Concern. http://www.who.int/ipcs/features/lead.pdf

[31] World Health Organisation (2011) Brief Guide to Analytical Methods for Measuring Lead in Blood. Inter-Organisation Programme for the Sound Management of Chemicals IOMC, WHO.

[32] Vuori, K. (1995) Direct and Indirect Effects of Iron on River Ecosystems. Annales Zoologici Fennici, 32, 317-329.

[33] Abdul, J.A., Sirajudeen, J. and Vahith, R.A. (2012) Studies on Heavy Metal Pollution of Ground Water Sources between Tamilnadu and Pondicherry, India. Advanced in Applied Science Research, 3, 424-429.

[34] Agu, C.C. (2006) Effect(s) of Chemical Fertilizer on the Water Quality of the Obinna River in Adanni, Uzo-Uwani Local Governmant Area of Enugu State, Nigeria. M.Sc. Dissertation, Enugu State University of Science and Technology, Enugu. 